Canadian University Music Review

Revue de musique des universités canadiennes

\title{
Music Education and Post-Secondary Music Studies in Canada
}

\section{Wayne D. Bowman}

Volume 21, numéro 1, 2000

Music Studies in the New Millennium : Perspectives from Canada Les études en musique dans le nouveau millénaire : perspectives canadiennes

URI : https://id.erudit.org/iderudit/1014479ar

DOI : https://doi.org/10.7202/1014479ar

Aller au sommaire du numéro

\section{Éditeur(s)}

Canadian University Music Society / Société de musique des universités canadiennes

\section{ISSN}

0710-0353 (imprimé)

2291-2436 (numérique)

Découvrir la revue

Citer cet article

Bowman, W. D. (2000). Music Education and Post-Secondary Music Studies in Canada. Canadian University Music Review / Revue de musique des universités canadiennes, 21(1), 76-90. https://doi.org/10.7202/1014479ar

\section{Résumé de l'article}

This essay questions the efficacy of conventional disciplinary boundaries in post-secondary music studies, boundaries that reductively define music education as a training ground for public school music teachers. Our expectations of music education and its sphere of influence have been far too modest. To the extent we segregate music education from the goals and objectives of music studies more broadly, we neglect our collective responsibility for the musical life of our country. We have focused inwardly, engrossed in our specialties, leaving the design of school music curricula and the fragile environments in which they must compete for survival to the whims of non-musician bureaucrats and politicians. We have been less than successful in our collective obligation to enhance the musical well-being of the country. Changing these circumstances is among our greatest challenges in the decades ahead.
All Rights Reserved ( C Canadian University Music Society / Société de musique des universités canadiennes, 2000
Ce document est protégé par la loi sur le droit d'auteur. L'utilisation des services d'Érudit (y compris la reproduction) est assujettie à sa politique d'utilisation que vous pouvez consulter en ligne.

https://apropos.erudit.org/fr/usagers/politique-dutilisation/ 


\title{
MUSIC EDUCATION AND POST-SECONDARY MUSIC STUDIES IN CANADA
}

\author{
Wayne Bowman
}

We generally speak of "music studies" as if they were straightforwardly and simply the study of music: learning about and/or developing proficiency in music, wherein "studies" are simply means to, and thus largely incidental to, the ends of musical expertise or fluency. But musical studies are not mere neutral means to musical ends, of significance solely by virtue of the music and musicianship they are concerned to impart. How we study, how we engage in our art with each other and with our students, and to what ends-the processes of musical education, in other words-ought to be vital concerns as well. My intent here is to address the matters to which this issue of the Canadian University Music Review is devoted from the perspective of music education: the discipline concerned to study, research, and refine the processes of teaching and learning music. It is important to reflect upon the ways we conceptualize the studies in which we engage our students; upon the ways music is taught and learned; and upon what, in addition to "music itself," may be taught and learned in those processes. In the end, I will raise what I hope to be challenging questions about our understanding of music education, its aims and obligations, its constituencies, and its effectiveness.

The last twenty-five years have been momentous ones within the academy, as much of what was once regarded as foundationally given has been subjected to vigorous and rigorous critique. Challenges to conventional truths have come from feminist and women's studies, from neo-Marxist and critical theory, from cultural studies, from semiology, from post-structuralism, and from discourse theory. Ideas like constructivism and performativity, deconstruction, and the decentring of identity have become fairly common currency in an era widely characterized as postmodern and post-colonial. Plurality and diversity have become more salient than unity and uniformity, undermining the comfort once afforded by notions like a priori truths, transcendental ideals, formal unity, and immanent or inherent meanings. Enlightenment ideals like truth, beauty, justice, and progress have become sites of struggle and contestation, and value claims once deemed absolute are now widely regarded as culturally and contextually relative. In education, critical pedagogy has heightened awareness of the subtle ways instructional practices construct and entrench power and privilege, and how at the same time they create marginals and marginality. In music, resistant, even disruptive readings, interpretations, analyses, and performances have begun to proliferate. The incorporation of ethnomusicology, jazz, and most recently, popular music studies into our curricula has caused us 
to re-assess once-comfortable understandings of music's nature and value, introducing an element of uncertainty where stability and security once prevailed. These are turbulent yet vital times: disturbing, challenging, yet at the same time filled with exciting possibilities for growth and transformation.

During this same period of time, the Canadian music education discipline has seen interesting developments. Computers and MIDI technology have been added to the arsenal of technical fluencies we expect graduates to demonstrate. We have become much more aware of the diversity of the world's musics, and much less inclined to act as if "ours" were the "only game in town"-even if nothing resembling consensus has begun to emerge on the extent to which Canadian music education should be multicultural, or what that might imply for practice. Music educators have also been active participants in that most Canadian of preoccupations, the effort to identify, define, and preserve distinctly Canadian culture - even if such identity remains as elusive as ever. And Canadian scholars in music education have contributed prominently and influentially to the discipline's professional literature on an international level.

Within the borders of a conventionally construed music education discipline, then, there has been substantial activity. On a deeper level, however-the foundational level of the discipline's identity and obligations-evidence of the dramatic shifts to which I alluded earlier can scarcely be detected. In contrast to the fundamental changes social and intellectual ferment have wrought in other areas of scholarly endeavor, the discipline of music education remains largely what it was twenty-five years ago. While the musical interests and practices of Canadian society have seen striking changes, conceptions of music education and its proper role in music studies have changed little. ${ }^{1}$ I believe it is imperative, and the time opportune, to examine our basic understandings and expectations of music education-its meaning, and its significance (actual and potential) in the Canadian system of post-secondary music studies.

On the conventional view, music education exists, quite straightforwardly and unproblematically, to train public school music teachers. Accordingly, music education's primary concerns are teaching music to children and young adults of school age, and preparing prospective teachers to function effectively within the public schools. The concerns of the curriculum and the discipline are, in other words, co-extensive with the perceived needs of prospective teachers of school music. The primary curricular concern at the post-secondary level is thus to prepare students efficiently and effectively for such careers, and current strategies to such ends remain what they have been for decades. Students destined for primary or elementary schools need to be immersed in Kodály or Orff methodologies; while those destined for secondary schools need to study conducting and engage in other technical studies designed to

1 Although I write about the Canadian system, I am confident that many of the arguments I advance are equally germane to the American system. Consider, for instance, the ever-escalating number of years of public school experience deemed necessary for most music education positions in American universities: such policies assure that music education programs are staffed by individuals with a particular kind and range of educational experience, reinforce the replicative focus of music education, and serve to keep music education synonymous with school music. 
develop their effectiveness as directors of concert bands, choirs, (less frequently) orchestras, and (increasingly often) large jazz ensembles. The music education curriculum is thus replete with "how-to" courses for school musicians. If and when the graduates of such programs seek advanced study, it is often to courses tailored to refining existing skills that they turn (conducting, for instance, or advanced studies in Orff or Kodály), rather than to courses of study designed to deepen or extend understandings of the nature and value of music, or to develop the kinds of skills and insights that might transform and revitalize music education.

Music education curricula thus exist primarily to replicate the status quo, to prepare students for extant instructional situations which-judging from curricular content-are assumed to have changed little over the years. Curricular modifications, when undertaken, tend to be concerned with doing better and more efficiently what is already being done, with rearranging furniture rather than basic redesign or reconstruction. Music education's purpose and purview are thus neatly delineated, and extend little further than preparing students to do what is currently required of instructors of music in school settings. That, I submit, is profoundly unfortunate: for music education, for university music studies, and for the musical life of the country.

Among the most pressing concerns facing post-secondary musical studies is a fundamental reconsideration of what education means, what education has to do with studying music, and what the discipline music education has to contribute to our understandings of such processes. An important part of what I intend to advance in this essay, my modest proposal, as it were, is that we need to work to make music studies more educational; that we all have a fundamental stake and crucial roles to play in that effort; and that a reconceptualized music education would have far more to contribute to musical studies than is presently the case. The convictions that motivate this proposal are simple, yet urgent: Canadian music education is in a precarious state, and is far too important to allow it to fall victim to benign neglect.

\section{RETHINKING DISCIPLINARY BOUNDARIES}

We must learn to think of music education not as the hermetic domain of school musicians, but as an endeavor in which all who make music and/or engage in musical instruction at any level and in any setting have a fundamental stake. This is not just to say that the school-directed and school-based efforts of music educators deserve the respect and support of musical scholars and performers, true though that certainly is. It is rather to assert that a music education curriculum worthy of the name should draw on the skills and abilities of musician teachers from backgrounds beyond the schools, and commit to developing the instructional and communicative skills of all musicians, not just those preparing for careers as school musicians. What is at stake-the vitality of Canadian musical life-is too precious and fragile to be entrusted to anything less than our most broad-based, concerted, and cooperative effort. Yet, our current disciplinary configurations compromise this collective responsibility to the musical health of the country by setting music education off to 
the side, treating it not as a shared obligation of utmost importance, but rather as a disciplinary specialty with only modest significance to music studies as a whole, or for students in other musical disciplines.

Since the view that the significance and meaning of music education needs reassessment is probably not widely held by those in the discipline, I risk serious misunderstanding by suggesting it might be better configured some other way. So let me make clear what I am not proposing. I do not suggest that musicianship constitutes sufficient qualification for teaching music in the schools, or that we redefine music education such that all musicians be considered music educators. Neither am I advancing the irresponsible notion that great musicians automatically and invariably make great educators, or that the expertise of music education professionals is easily come by or insubstantial. What I do want to advance is that music education is too important to be left to music educators alone; that all musicians-in-training need to be prepared for educational roles they will inevitably have many opportunities to assume; and that musical education takes place in settings well beyond the public schools. Schools are vitally important sites for music education, and there is urgent need to attend to and improve what we do there. But they are not, neither should they be, the only places where music education takes place: indeed, while schools are quite well-suited to certain ranges of music educational practices, they are poorly suited to others. Just as we have come to recognize the plurality of music, then, we need to acknowledge and strategize a plurality of musical educations: a broader, more inclusive purview that recognizes the validity and value of a variety of educational settings and roles, and provides numerous points of access to musical education-not just for children and young adults, but across the entire span of human life. We need, in other words, to create and capitalize upon alternative sites and strategies for educating musically.

I am suggesting, too, that music education should recognize and find ways to capitalize upon the conspicuous educational experience and expertise of colleagues in music's other subdisciplines-performers, composers, conductors, and so on. The insights of master teachers are valuable educational resources, and the inspiring models they offer our students are important instructional assets. We are wrong to overlook and neglect potentially valuable contributions to the cause of music education by such individuals simply because they are not "music educators" in the sense of that phrase to which we have grown accustomed.

That conventional disciplinary boundaries have not served the aims and goals of educating musically as well as we would like is a fairly innocuous suggestion in the abstract. But disciplinary identities define, among other things, who "we" are and are not; and modifying such identities requires significant measures of cooperation and trust. Neither is it the case that disciplinarity itself must somehow be dissolved, since, after all, disciplinary boundaries are constructions that serve certain ends quite well. The fact is, however, that disciplinary boundaries do not and cannot serve all ends equally well, and that too often the rigour they are intended to ensure becomes a kind 
of rigor mortis. Our concern, then, is not to dismantle disciplinarity, but to find ways to make boundaries more porous and permeable, flexible enough to permit the interactions essential to growth and change. I submit that music education has suffered for its isolation from critical developments in other fields, and it needs to be reconceived in ways that revitalize the efficacy of its conventional (school music) mission; in ways that capitalize on what it has to offer students and teachers in music's other subdisciplines; and in ways that ensure ongoing energetic exchanges across disciplinary boundaries on matters of collective educational concern to post-secondary music studies. Music education needs to be the place where all music's subdisciplines converge on matters educational, instructional, pedagogical, and curricular. We need to learn to conceive of music education as that discipline whose concern is the preparedness of musicians to teach and communicate about their art, meeting the pedagogical, instructional, curricular needs of all musicians, and of amateurs and non-musician listeners as well. On the broadest level, then, the concern of Canadian music education is no less than making Canadian society more musical, attending to the health and vitality of Canadian musical life. In that important effort, everyone in post-secondary music studies has a stake and a role to play. Music education so conceived is too important to isolate, delimiting its presumed range of potential relevance to its function in preparing teachers for the schools, crucial though that function undeniably is.

\section{EduCATING Musically ${ }^{2}$}

I have urged a need to reconceptualize what is meant by music education, and have suggested such an undertaking would have significant implications for musical studies in general. So far, I have spoken primarily about the ways the music education terrain tends to be demarcated institutionally-about whose responsibility and interest it is. But the issues with which we need to concern ourselves are more fundamental yet. I submit that we have often been too quick to assume that the purpose of music studies is to impart musical knowledge and skills, and that our instructional obligation to our students and our art is fulfilled in the development of musicianship. However, crucial though such abilities and understandings are, they do not in themselves constitute outcomes that are educational. It is not my intent to resurrect the tired old debates over the differences between conservatories and universities, or to dichotomize musical instruction into mutually exclusive categories of training and education. I do think it useful and important to contemplate this latter distinction, however: to ask ourselves in what ways musical education may be usefully distinguished from musical training, and to ask which more nearly typifies post-secondary music studies. I raise the issue because it seems to me that we generally train more than we educate. I make this assertion not to derogate or disparage, but rather with the constructive intent of asking how music instruc-

2I make a much more detailed study of the idea of educating musically in a chapter by that title, forthcoming in the Second Handbook of Research on Music Teaching and Learning, ed. Richard Colwell (Oxford University Press). 
tion with genuinely educational intent differs from that which seeks only to train-on the assumption, one hopes justified, that it is the educational alternative to which post-secondary music studies appropriately aspire.

We need not dwell at length on the nature of training: it consists, presumably, of the development and refinement of relatively clear-cut skills and practical knowledge. Since training may variously entail a broad range of cognitive involvements, it is not a question of being less mindful or less intelligent. What I would rather stress is the relatively clear-cut nature of the task, a relation between instructional means and outcomes that can be stipulated at the outset, one that provides uncontroversial criteria by which the effectiveness of teaching and learning can be gauged, and progress monitored. Though often highly complex and sophisticated, training tends to be technical in nature: its concern is primarily with the efficiency with which self-evident ends are attained. In contrast, one of the salient characteristics of education properly so-called is the absence of such clear-cut criteria, the possibility of multiple, even divergent outcomes. While training is necessary to education, it is not sufficient. Whereas the aims of training are generally beyond question, those of education seldom are. Most importantly, in training, the successful attainment of ends justifies the means by which they are reached, while in education that is emphatically not the case: for the point of education is not just learning about music, for instance, or developing musicianship-it is, rather, a question of what else one learns and of who one becomes through such studies and experiences.

To put it more directly, education is concerned with the development of character, dispositions, attitudes, and identity. Instruction with educational intent is thus not primarily technical, although it draws on technical abilities: it is ethical, concerned with developing habits of "right action" where, because of the variability and unpredictability of circumstances, what constitutes "rightness" cannot be unequivocally stipulated in advance. Thus, musical education is fundamentally concerned with what one knows about and can do as a result of musical instruction; but it is concerned just as importantly, or perhaps more so, with the kind of person one becomes through that process. And although such concerns can never be prescribed and dispensed like medications, neither can they be neglected or ignored-at least if one's aim is truly to educate.

To educate musically, I am asserting, is considerably more complex and ambitious than to develop musicianship (as if that were not complicated enough!). The human impact of instruction - the kinds of attitudes, capacities, tendencies, and dispositions it imparts-are concerns fundamental to education, and are never beside the point. I trust the significance of these points is evident. We must not assume that our instructional and curricular obligation to our students and our art begins and ends with the development of musicianship, or that the purpose of engaging in music studies is straightforwardly the development of musical knowledge and proficiency. How we teach, and how we in turn teach our students to teach, are crucial educational matters. Learning about music or learning to engage in it, even with significant fluency and 
expertise, must not be regarded as an "inherent good"; for the educational worth of such learning does not inhere in either the music or its making.

I recognize that this makes of instruction a moral, indeed even a political, undertaking: a point some may wish to resist. It is certainly an orientation that contrasts in significant ways with music studies as conventionally understood. I would argue, however, that it is an inescapable conclusion: both instruction and music are fundamentally social phenomena, and it is profoundly reductive to conceive of them otherwise. Teaching music and engaging in music making are acts that are intimately linked to the production of identity, both individual and collective. As such, the teaching and the making are always acts with unavoidably sociopolitical and ethical dimensions. We may choose to ignore these facts, but we cannot change them. And to ignore them is to engage in untheorized practice, ${ }^{3}$ practice that may or may not have genuinely educational value, practice that may actually cause harm, even as it achieves its more immediate, instrumental objectives. To educate musically, then, is not just to teach children and young adults to sing, or to play, or to read, or even to compose music. It is always more, and the nature of that "more" warrants our closest collective scrutiny. In developing musicianship, we manage thought, emotion, and body - and to an extent shared by few other human undertakings. ${ }^{4}$ In identifying and nurturing talent, we shape self-esteem and self-expectation and character. When we train without educating at the same time, we create and sustain dependency, thwarting the imagination and creativity that are music's life's blood.

Because its outcomes are manifold and unpredictable, education must, unlike training, take its chances. But such chances must be taken if we are to make good on our claim and our obligation to educate musically. Neither does the fact it is not amenable to a technique mean we cannot enhance or optimize the likelihood of its attainment. It only means we must be cognizant of and sensitive to what is being taught through the musical experiences in which we engage students for instructional purposes-and that is invariably and unavoidably more than "musicianship," or "the music itself." We need to become much more attentive to the ways our discursive and instructional and musical practices shape the lives and character and identities of our students. If we content ourselves with training and a technical curriculum, we will attract, train, and

\footnotetext{
3"Musical performance is untheorized practice," alleges Roberta Lamb: "It is not praxis; it is what we musicians do because it is what we do ..." Roberta Lamb, "Tone Deaf/Symphonies Singing: Sketches for a Musicale," in Gender In/forms Curriculum: From Enrichment to Transformation, ed. Jane Gaskell and John Willensky (New York: Teachers College Press, 1995), 126.

4 In e-mail correspondence related to a yet unpublished collaborative article on ethics, talent, and identity formation, Joyce Bellous of McMaster University writes: "[T]he problem with talent and identity in the musical arena has to do with the totality of the teacher's involvement over the learner-body, mind, spirit. To be musical and to develop the gift, the child's body is taken over by someone else who knows how the body should stand, look, posture itself, move, when and where. The influence of the musical teacher over the musical student is far more intrusive than the math teacher over the math student ... It didn't used to be that way. The English teacher, and every other teacher, had something to say about how the learner sat, held a pencil, looked toward the front and conveyed attentiveness. I think it is fair to suggest that only music remains in the domain of body management, in this sense, and to the extreme that it does."
} 
produce technicians-highly skilled and knowledgeable technicians, perhaps, but technicians all the same. ${ }^{5}$ The vitality of musical life in Canada requires and deserves more.

\section{“ThEORIZING" MUSIC AND EDUCATION}

In the first section of this essay I argued the need to rethink the constituency and the institutional boundaries of music education. And in the second I urged the importance of engaging in musical instruction with explicitly educational intent: of assuring that instructional and curricular arrangements develop the attitudes, dispositions, and capacities characteristic of the educated. I now want to bring these threads together, suggesting that, its important responsibility for school music notwithstanding, the music education discipline should be first and foremost a site for theorizing, researching, and improving musical teaching and learning; or, to put it in terms introduced above, we should recognize it as that discipline whose responsibility is to assure the educational potential of musical studies is realized, wherever and whenever music is taught and learned.

If this sounds ambitious, that is a function of the modesty of our historical and current expectations. For it is simply to suggest that music education be concerned with teaching and learning music, wherever and whenever they occur. And it is simply to urge that music education make good on the commitment implicit in its name, to advancing the achievement of educational outcomes through musical instruction. I also have in mind, however, that what we call music theory in our curricula is generally not theoretical study at all, but rather the study of principles of harmony. This is a fairly mundane observation, but our continued neglect of true theory in musical studies is far from a mundane concern; and it is time we undertook to address it. I raise the issue here because I believe a music education discipline less modestly conceived is a reasonable place to begin to redress that neglect. ${ }^{6}$ The music education discipline I am suggesting we envision is one given to theorizing musical and instructional practices in ways that render implicit assumptions explicit, that subject habitual and familiar practices to critical scrutiny with the intent of improving music teaching and learning. This is not the intellectualization of practice, but the critical study of both musical and instructional praxis, in ways whose success would be gauged by their capacity to improve and transform music instruction and thereby, the musical life of the country.

The primary reason this does not happen currently in music education is simply that the discipline has not seen this as its responsibility, as its particular concern or challenge. But disciplinary identities are institutional constructions,

5 Equally important, where we as educators fail to critically scrutinize and revise our instructional practices in ways that take into account the forms of community they produce and perpetuate, we function as potential agents of social injustice-a possibility rendered more potent by the deeply entrenched ideology that maintains music's autonomy and aloofness from issues of politics and power.

6 In certain respects, this is the most immodest suggestion in this essay. I say this because, all too often, music education as currently constituted is overwhelmingly "how-to," and profoundly "un-theoretical." Some may wish to counter that such a fundamental and radical reorientation is simply an impossibility. I think its potential benefits worth the effort, however considerable, and too important not to try. 
after all. What music education "is" is a function of what we have asked, expected, and permitted the discipline to be and do, and I believe we have been too modest in these requests, expectations, and permissions. We need to ask far more of music education, of what we expect it to deliver and contribute to musical studies; and since its potential contributions benefit us all, these more rigorous expectations must be matched by more generous support and cooperation. So long as music education remains isolated within its own fiefdom, its contribution to musical studies will be modest. And so long as we cling to the naive conviction that educational expertise is inessential for the musically talented, music studies' contribution to the musical welfare of our country will fall short of its potential. At the same time, we must recognize that mundane, pedestrian curricula will never attract or retain the imaginative and creative, and where they do, they will extinguish such aptitudes rather than nourishing and rewarding them. Accordingly, it is imperative that we implement the kind of curricular and instructional changes in music education that the best and the brightest will find stimulating and fulfilling. Music education curricula frequently look more like technical obstacle courses than experiential terrain designed to attract and stimulate imaginative, creative musicians concerned to understand their art better and share it with others more effectively.

The music education discipline I am urging us to envision here is one where musical and intellectual rigour are brought together, and forged into a powerful synthesis of theorized practice and articulate, contagious passion for helping others grasp what musical engagement uniquely offers education. It is the place in post-secondary music studies where curricular and instructional strategies and structures are studied and researched, where foundational assumptions (both musical and educational) are submitted to rigorous critique. It is centrally interested in questions and questioning, committed not so much to replication as it is to transformation and vitalization. It is concerned to develop independent imagination and the dispositions conducive to persuasive leadership. It is a socially committed discipline, concerned with the educational practicalities of the full range of musical meaning, and the broadest possible range of pedagogical possibilities. To these ends, it requires extensive input and attention from a broad range of musical subdisciplines not traditionally aligned with music education: it needs to move beyond its conventional foci of band, choir, and (elementary) general music, to concerns like composition, improvisation, technology, popular and folk or "world" musics, and more. The music education discipline I am urging we envision also draws on the powerful and provocative insights of cultural studies and critical pedagogy to enrich our understandings of the processes of educating and musical engagement. And finally, the music education discipline I am urging we envision is a researchoriented and research-guided discipline, whose students and professors are actively engaged in and deeply committed to the advancement of our understandings of music teaching and learning. 


\section{Music IN SchOOLS ${ }^{7}$}

To recommend against equating music education with school music is to caution against too narrow a conception of the discipline and against expectations of it that are consequently too modest. It is emphatically not to suggest commitments to preparing school musician-teachers be abandoned. On the contrary, it is imperative that this remain one of music education's major concerns, and indeed, that we make significant improvements in the efficacy with which that function is generally fulfilled. However, we also must recognize and provide for music educational needs in settings beyond the schools, for it is unreasonable and unrealistic to expect the schools alone to meet all the music educational needs of Canadian society. Because there are limits to what can be achieved in school settings (or any setting, for that matter), we need to invest our educational resources more broadly. There is nothing condemnatory in asserting that school-based music programs alone cannot accomplish everything needed by a musical society, and nothing unreasonable in suggesting that musicians not comfortable with school environments for whatever reasons should nonetheless engage in the systematic study of instructional, pedagogical, curricular, and other foundational concerns pertinent to their art.

I believe a more broad-based and inclusive conceptualization of music education will not detract from the status of music in the schools, but rather will enhance it; for, at least some of the difficulties faced by school music programs can be traced to a failure by university schools of music to exercise the kind of leadership musicians in the schools have a right to expect of them. To the extent that music education has been regarded straightforwardly as the preparation of prospective teachers to engage in the kinds of musical activities currently typical of school music programs, universities have failed to make good on their responsibility to provide vision and leadership. Programs have been designed more with a view to reproducing the status quo than to improving upon it or to developing viable alternatives. Moreover, to the extent that school music has been regarded as the exclusive concern of a narrowly defined and insular music education discipline, the temptation has been to rationalize school music matters as "someone else's problem": what goes on musically in the schools is not a matter in which university music studies collectively have a stake or an interest. The neglect of school music must be recognized as a failure to exercise proper leadership, the result at least in part of institutional/disciplinary arrangements that permit the continued rationalization of such neglect.

These are claims that warrant considerably more elaboration than I am able to give them here. But let me be clear what I am alleging. Musical studies within Canadian schools are waning. Although early childhood and elementary school offerings were the first to be affected, the ripple effects can now be detected in middle school and secondary programs-and, increasingly, in students

7 While writing this section, I engaged in several stimulating exchanges of ideas on the topic with Teresa Lee. I wish to acknowledge her provocative insights into these issues, and to express my gratitude for the thought processes they engendered. 
entering university music studies. While this has happened, the voices of those involved in music studies at the post-secondary level have been eerily silent. Our complicity in such problems extends well beyond our lack of awareness and our unresponsiveness, however: I believe we must accept a measure of the blame. While we have gazed inwardly, engaged in musical studies and activities we find stimulating and rewarding (and occupied with the efforts necessary to secure our bids for tenure and promotion), we have left the design of school music programs and the fragile institutional/ecological environments upon which they depend for survival to non-musicians and to the whims of politicians and bureaucrats. Too often we have accepted and dutifully complied with directives that threaten to compromise the vitality of school music curricula, when our expertise and insight into the unique needs and benefits of musical experience and our deep commitments to the country's musical life should have made us vigorous and vocal opponents.

Neither have we attended as closely as we should to the quality of the "product" we have put before the public in their schools. Too often have we prepared followers rather than leaders in the name of music education: people well-suited to fitting into existing patterns, adapting to expectations, and disinclined to rock the boat or work for meaningful change. Nor have we resisted strenuously enough the tragically flawed logic by which school musicians are presumed to require less sophisticated musical skills and understandings than their counterparts in other musical disciplines. A corollary of this view-indeed, part of what sustains it-is the belief that school music is concerned primarily to develop, from among presumed "lesser talents," appreciative audiences and consumers of music. Since schools are largely unsuited to the development of sophisticated musical skills and understandings, that job can be left to the conservatories; and individuals with lesser musical expertise can attend to the more mundane task of refining the public's musical tastes. Where such profoundly misguided sentiments as these prevail within the very institutions that should be working to eliminate them, it is not at all surprising to find support for school music waning. We expect far too little of musical instruction in the schools, and minimal expectations seldom beget impressive results. ${ }^{8}$

Failure to appreciate the profound importance of musical instruction in the schools; failure to develop meaningful ways of reaching and engaging students who are not performers or who perform on non-traditional instruments; failure to assure that school music instruction is offered by the best and the brightest: these conspire to create an inevitable downward spiral. Where our most influential decision and policy makers have had no musical experience-or worse still, where experience in mediocre programs has "turned them off" rather than "on" to musical experience-we can reasonably expect to reap only what we have permitted to be sown. That decision-makers are skeptical about the importance of musical experience to education is hardly surprising when

8 The statement that we expect too little of musical instruction in the schools must not be mistaken to mean that we expect too little of those currently teaching there. That is not at all my intent here. 
they have had no such experience themselves, or where experiences they have had were superficial and uninspiring - a possibility made ever more likely by our failure to exercise proper rigour in the selection and education of musicians destined for the schools. Neither, incidentally, is this a scenario played out only within elementary and secondary schools: for the same indictment can be made of many university music schools. Their inward focus and preoccupation with instruction for "majors" often manifests itself in a neglect of so-called "service" courses for non-majors, courses whose nature is apparently presumed tangential to the "true" institutional mission of developing talent, musicianship, and advanced levels of knowledge.

Also complicit in this state of affairs is a structural-formal bent in music studies which emphasizes literal meanings over figurative ones, and knowledge about music over musical experience. From this perspective, what is crucial to the defense of musical studies in education is its credibility and status as a "subject," among the "other subjects." Musical instruction is thus concerned primarily with imparting knowledge about music, and the value of such instruction is a function of the knowledge it transmits. The problem with this is its neglect of the fundamentally social nature and bodily roots of musical experience-the things that are arguably most distinctive and salient about music, and that are therefore most crucial when it comes to justifying musical instruction.

It may be objected, and fairly, that these arguments fail to acknowledge one of the most fundamental facts about post-secondary education in Canadian universities: that the preparation of teachers for the schools is generally the jurisdictional responsibility not of schools of music, but of faculties and colleges of education. Although music education is grounded in both musical and educational studies, such studies are widely considered discrete disciplines, organizationally isolated in separate faculties within many Canadian universities. As a result, music education and music educators often find themselves situated precariously astride sharply demarcated institutional boundaries; and all too frequently what should be a diasporic identity becomes a schizophrenic one, where a presumed mutual exclusivity of education and music works to the detriment of both. This need not be an insurmountable obstacle; but its satisfactory resolution will require the problem be acknowledged and energetically confronted. To continue to concede the mutual exclusivity of music and education is to profoundly compromise music education-both in the broader sense I have been advocating here, and in the narrower, school-music sense against which I have been arguing.

Where music and education are regarded as discrete disciplines, music education generally receives inadequate attention from either. Moreover, where music students are not socialized as musician-educators, those who do teach in schools tend to identify not as music educators but as band directors, choir directors, or elementary music specialists, each with separate professional organizations, meetings, and journals. This situation is seriously detrimental to the creation of a community of music educators and to the effectiveness of our collaborative efforts to musically educate Canadian soci- 
ety. Furthermore, where such conditions prevail, music students who choose not to pursue school teaching careers are unlikely to undertake educational studies, despite inevitable eventual involvements as teachers, and despite a shared interest in and responsibility for improving the musical vitality of the country. On the one hand, then, we find school music teachers splintered into special interest groups (band and choir directors, self-described "jazz educators," Orff or Kodály practitioners) with little attention to their common mission or the needs of the profession as a whole. On the other, we find master pedagogues and brilliant musician-teachers who, with no apparent sense of irony, disavow knowledge of, or interest in, music education.

The institutional boundaries we have erected between musical and educational studies work not just against effective dialogue and communication, but against the effective musical education of the country. We have been less than successful in the important task of creating a community commonly committed to the musical well-being of Canadian society-a community in which all musicians have both an interest and a stake. In our efforts to demarcate and fortify disciplinary turf, we have seriously neglected the musical education of the country.

\section{CONCLUDING REMARKS}

The music education discipline remains more or less what it has been for years, the training ground for school music teachers. There is nothing wrong with that, and a good deal that is right. Such preparation is, after all, one of music education's crucial functions and responsibilities. I have expressed concerns, however, about the insularity and narrowness of the discipline so conceived: about its potential neglect of musical and educational issues beyond those immediately relevant to schools and school culture; about its apparent disinclination to maintain the kind of disciplinary interactions and exchanges that keep a discipline vital, relevant, and growing; and about its unfortunate tendency to marginalize musical education within the context of music studies. The importance of music education to music studies extends well beyond the preparation of teachers of music for elementary and secondary level schoolbased instructional responsibilities.

Although I have focused extensively upon issues stemming from disciplinary insularity, I have also urged that we in music studies need to attend more closely to the educational significance of our curricula and instructional practices. The specifically educational obligation of post-secondary music studies must not be taken for granted or presumed to follow automatically from having studied music or developed significant musicianship. I have suggested that we need to think carefully about the ways we intend musical education to differ from musical training. And I have indicated my conviction that the attitudes, capacities, and dispositions developed through music studies are among the educational aims to which we need to direct our collective attention; for it is upon the dispositions characteristic of the educated person-independence, flexibility, comfort with change, leadership, and so on-that the continued musical vitality of the country will ultimately depend. Becoming musically 
educated involves more than engaging in advanced musical studies, and we all have an important stake in assuring the educational aims of musical study are realized.

While I have argued that music education must be conceptualized more broadly than "school music," I have also claimed that school music programs are in trouble and urged that post-secondary music studies have a collective responsibility to address the problem. Since a musically vital Canada is impossible without vital musical programs in the country's schools, we simply cannot afford to ignore curricular trends that undermine the musical health and viability of school-based programs. Neither can we subscribe to the complacent view that school music programs are simply the machinery for delivering traditional instruction to a student population whose musical needs and interests have changed little over the years. We must develop more pluralistic understandings of the forms musical education can take, the settings in which it can occur, and whom its potential recipients may be. We must learn to design curricula in ways that are more flexible and responsive to local circumstances-curricula into which change, evolution, and diversity are built as fundamental features. Above all, we must learn to exercise more effective leadership in the design and delivery of school-based instruction: leadership whose overall effectiveness is gauged by nothing less than its success in creating and maintaining a musically vital Canadian society.

Since efforts like these require collaboration among a wide range of interests and specialties, one of our most pressing needs is to learn how to forge disciplinary alliances and sustain interdisciplinary communication more effectively. ${ }^{9}$ Such skills will not be developed without deliberate and sustained effort. Interaction and cooperation among music educators, other musicians (many of whom are also educators, if not in the conventional sense), and education professionals is imperative. It is also clear that a distinctly Canadian solution must necessarily acknowledge and involve the conservatories, the colleges, the festivals, the registered music teachers, and others-in an effort to clarify roles and devise strategies for achieving the educational goals we hold in common.

I believe there is also considerable merit in attempting to achieve a pattern of increased diversity among post-secondary music curricula. Such diversity would be in keeping with Canada's distinctive commitment to cultural pluralism and would lend itself well to the increasing cultural diversity of the country. The system currently consists of programs which are more or less cookie-cutter copies of one another, as if it were utterly clear what music studies must consist of, and but one correct configuration for them to take. Neither of these assumptions is valid. Canadians are unencumbered by the standardizing influence of a national accreditation body, as are our neighbours to the South. If we

9Claire Detels makes a passionate plea for interdisciplinarity in music in her recent book, Soft Boundaries: Re-visiting the Arts and Aesthetics in American Education (Westport, Conn.: Bergin \& Garvey, 1999). I have reservations about her proposals, many of which are quite specific to American institutional issues and culture, and I think her version of interdisciplinarity is not nearly ambitious enough. However, her assessment of the basic problem is cogent and persuasive. 
are serious about change and about meeting the changing needs of the country-and I believe we must be-we should see more diversity, more innovation, more originality, more experimentation, and more evidence of a distinctly Canadian "spin" on the processes of musical education. That is unlikely to happen, however, unless and until we develop a vigorous system of Canadian masters and doctoral programs in music education, programs that both cater to and educate the leadership necessary for the distinctive musical needs of a culturally vibrant Canadian society.

Music education is too important to be left to music educators. I make this provocative assertion not to denigrate my colleagues and profession, but to remind us all that the educational process is a crucial component in musical teaching and learning, whenever and wherever they are undertaken. As such, while music education is rightly concerned with school-based instruction and curricula, its purview must not be restricted to those needs and challenges. To the extent music education remains the training ground for school music teachers rather than an endeavour in which all serious musicians, professional or amateur, have a stake, and of which all are at the same time beneficiaries, we will fall short of the broader goal of creating a vigorously musical Canadian society-one where music is a fundamental part of national identity and the fabric of everyday life.

\begin{abstract}
This essay questions the efficacy of conventional disciplinary boundaries in post-secondary music studies, boundaries that reductively define music education as a training ground for public school music teachers. Our expectations of music education and its sphere of influence have been far too modest. To the extent we segregate music education from the goals and objectives of music studies more broadly, we neglect our collective responsibility for the musical life of our country. We have focused inwardly, engrossed in our specialties, leaving the design of school music curricula and the fragile environments in which they must compete for survival to the whims of non-musician bureaucrats and politicians. We have been less than successful in our collective obligation to enhance the musical well-being of the country. Changing these circumstances is among our greatest challenges in the decades ahead.
\end{abstract}

